\title{
STUDY OF EFFECT ON TEETH OF INTERMITTENT FLUORIDATION OF A COMMUNITY WATER SUPPLY
}

HARRY W. BRUCE, JR., B.S., D.D.S., M.P.H., AND BENJAMIN F. GUNTER, D.D.S., M.P.H.

University of Michigan, Ann Arbor, Mich.

$\mathrm{T}$ HE city of Pulaski in Giles County, Tenn., affords an area in which the intermittent fluoridation of water can be studied. The effect on the teeth of children of intermittent fluoridation of a municipal water supply has not been reported.

The Pulaski water supply is derived from Richland Creek, while the surrounding area is served by ground water. The intermittent fluoridation of the water supply of Pulaski possibly is related to the water saturation in the ground. Alexander ${ }^{1}$ suggested that when the ground is completely saturated with water there is less passage of water over the phosphate rock and therefore less solution of fluorides. The fluoride content of Pulaski water varies from 0.2 to $1.3 \mathrm{ppm}$. The ground waters of the adjacent study area in the county have unknown fluoride values.

The condition of the teeth of the children using the municipal water supply of Pulaski ( 0.2 to $1.3 \mathrm{ppm}$. F.) has been compared with the condition of the teeth of the children living outside of the eity using ground water (wells or springs) of unknown fluoride content, to determine whether a correlation exists between the surface water supplies of known high intermittent fluoride content and the ground water supplies.

Dean, ${ }^{11}$ Arnold, ${ }^{3}$ Klein, ${ }^{17}$ and many other investigators have shown that groups of children who consume waters containing small amounts of fluorine (0.5 ppm. or more) experience less dental decay than do comparable groups of children who use fluoride-free water. Arnold ${ }^{3}$ has shown that children who are born and reared in communities whose domestic water supplies contain more than $0.5 \mathrm{ppm}$. fluorine experience less dental caries than do children living in areas where the domestic water supply is fluoride-free. Arnold ${ }^{2}$ has proposed that water containing 0.5 to $0.7 \mathrm{ppm}$. fluorine in the southwestern United States might have an effect equal to that of water of 1.0 to $1.5 \mathrm{ppm}$. fluoride in the north central section, and concluded that only a small amount of furorine is necessary to produce the desired effects.

McKay, ${ }^{33}$ Churchill, ${ }^{30}$ Smith, $^{34}$ and Dean $^{6,7,31}$ have demonstrated that small quantities of fluorine consumed in a water supply during tooth development may result in mottled enamel, 1 ppm. representing a safe threshold. ${ }^{31}$

Russell ${ }^{19}$ has reported a study of a community in which the water supply was accidentally fluoridated to a mean level of $1.15 \mathrm{ppm}$. fluorine for eighteen months. On the basis of caries prevalence, he found no demonstrable inhibition of dental caries in the younger children of the community. In the same group he did find that 1 per cent of the girls and 5 per cent of the boys had

Received for publication, May 23, 1952; revised by author, Sept. 19, 1952. 
very mild or mild dental fluorosis. Klein, ${ }^{15}$ in an investigation of a community water supply that was accidentally fluoridated (1.2 to $2.2 \mathrm{ppm}$. fluorine), found a marked reduction in the incidence and prevalence of dental decay in persons born in or migrating to the area. He concluded that the deciduous teeth were protected to a greater extent against caries in those children to whom the fluoride city water was available than among those children who used farm well water, even though their homes were in the same area. Children born, reared, and residing in the fluoride area who had consumed the city water exhibited lower DMF rates at every age than did children. who consumed the city water in the nonfluoride area.

Hardgrove and Bull ${ }^{13}$ have established a "def" rate of 1.27 for children 5 to 6 years of age who consumed water with a fluoride content of $2.3 \mathrm{ppm}$. A group that consumed water containing $.05 \mathrm{ppm}$. had a def rate of 4.82 . Bull ${ }^{5}$ claimed that the def rate for deciduous teeth increases when the fluorine content falls below $2 \mathrm{ppm}$. while the DMF rate remains as low at $2 \mathrm{ppm}$. as it does at 1 ppm.

$V_{\text {elu }}{ }^{28}$ reported observations which show that mottled enamel exists in many phosphate zones of North Africa. He has demonstrated that this dystrophy is only an occasional symptom of chronic intoxication resulting from prolonged consumption of water which has flowed through layers of phosphate.

Dean ${ }^{8}$ observed mottled enamel in a few families using ground water which had traversed rock phosphate beds in Hickman and Maury counties of Tennessee. The number of children examined in the areas was few, but the prevalence of mottled enamel was high, suggesting the presence of fluorine in this area. Smith and Whitlatch ${ }^{22}$ have classified the three types of phosphate rock that occur in Tennessee as brown, blue, and white rock. The brown rock, according to Alexander, ${ }^{1}$ contains the highest amount of phosphate and fluoride as F. The principal sources of the brown rock deposits are the Hermitage, Bigby, Cannon, and Leipers formations. ${ }^{23}$ The chemical composition of the Bigby layer of phosphate rock shows the fluoride content as $F$ to be 2 per cent. $^{24}$ The phosphate areas around Pulaski, Tenn., are the Bigby and Cannon layers of the brown rock containing as much as 3 per cent fluoride as F. ${ }^{25}$

\section{METHOD}

Mouth mirror and explorer examinations were made of the teeth of white children 6 to 17 years of age in Pulaski elementary and high schools. Similar examinations of the same age groups were completed in Fayetteville, Tenn., elementary and high schools. The Fayetteville children were used as a control group. The water supply for Fayetteville comes from springs in the highland rim of Tennessee and is constantly fluoride-free. We completed all examinations using the same methods. The caries diagnosis utilized by each of us was standardized.

The information concerning the source of water and the period of use of a particular water was obtained from each child by the schoolteachers from school records and questioning of the child. The dentists checked the teachers' information by questioning each child during the examination. 
Table I presents the decayed, missing, and filled permanent teeth (DMF) per child in Pulaski and Fayetteville. It will be noted that there is a lower DMF per child at each age group of the Pulaski children when compared with the Fayetteville children. Statistical analysis reveals that, with the exception of the 6 year age group, all differences in the $D M F$ rates per child are significant.

Table I. Decayed, Missing, and Filled Permanent Teeth Per Child (DMF Per Child) in Pulaski and Fayetreville in 1948

\begin{tabular}{|c|c|c|c|c|c|c|c|}
\hline \multirow[b]{2}{*}{$\begin{array}{l}\text { AGE } \\
\text { (YR.) }\end{array}$} & \multicolumn{4}{|c|}{ FAYETTEVILLE } & \multicolumn{3}{|c|}{ PULASKI } \\
\hline & $\begin{array}{c}\text { NO. OF } \\
\text { CHILDREN }\end{array}$ & $\begin{array}{l}\text { TOTAL NO. } \\
\text { DMF TEETH }\end{array}$ & $\begin{array}{l}\text { DMF } \\
\text { PER }\end{array}$ & $\begin{array}{l}\text { TEETH } \\
\text { CHILD }\end{array}$ & $\begin{array}{l}\text { NO. OF } \\
\text { CHILDREN }\end{array}$ & $\begin{array}{c}\text { TOTAL } \\
\text { NO. DMF } \\
\text { TEETH }\end{array}$ & $\begin{aligned} \text { DMF } & \text { TEETH } \\
\text { PER } & \text { CHILD }\end{aligned}$ \\
\hline 6 & 47 & 30 & .64 & \pm .14 & 87 & 44 & $.51 \pm .51$ \\
\hline 7 & 43 & 101 & 2.34 & $\begin{array}{l} \pm .23 \\
\end{array}$ & 105 & 65 & $.62 \pm$ \\
\hline 8 & 43 & 127 & 2.95 & \pm .25 & 72 & 75 & $1.04 \pm$ \\
\hline 9 & 56 & 251 & 4.48 & .40 & 75 & 140 & $1.87 \pm$ \\
\hline 10 & 46 & 226 & 4.91 & .53 & 86 & 180 & $2.09 \pm$ \\
\hline 11 & 57 & 388 & 6.81 & .61 & 78 & 177 & $2.27 \pm$ \\
\hline 12 & 48 & 344 & 7.17 & $\pm \quad .72$ & 75 & 251 & $3.35 \pm$ \\
\hline 13 & 60 & 555 & 9.25 & .56 & 106 & 426 & $4.02 \pm$ \\
\hline 11 & 98 & 945 & 9.64 & \pm .53 & 91 & 407 & $4.47 \pm$ \\
\hline 15 & 27 & 319 & 11.81 & \pm 1.48 & 79 & 395 & $5.00 \pm$ \\
\hline 16 & 13 & 120 & 9.23 & \pm 1.45 & 32 & 220 & $6.88 \pm .81$ \\
\hline 17 & 3 & 35 & 11.67 & $\pm \quad .33$ & 8 & 50 & $6.25 \pm 1.84$ \\
\hline $6-\overline{17}$ & 541 & 3441 & 6.35 & .22 & 894 & $\overline{2430}$ & $2.72 \pm .01$ \\
\hline
\end{tabular}

Table II presents the data on children in Pulaski and Fayetteville who have no DMF teeth. When age groups are compared there is a marked difference in the percentage of children with DMF teeth, but since the numbers are small in the Fayetteville group, no groups are statistically significant. There is a significant difference in the percentage of all the children in Pulaski who have no DMF teeth compared with all those from Fayetteville.

Table III presents comparisons of the def rates per child of the Fayetteville and Pulaski children. Although the def rates are lower for each age

Table II. Children in Pulasiz and Fayet'teville Having No DMF Teeth in 1948

\begin{tabular}{|c|c|c|c|c|c|c|}
\hline \multirow[b]{3}{*}{$\begin{array}{c}A G E \\
\left(Y R_{.}\right)\end{array}$} & \multirow{2}{*}{\multicolumn{3}{|c|}{ FAYETTEVILLE }} & \multicolumn{3}{|c|}{ PULASKI } \\
\hline & & & & \multirow[b]{2}{*}{$\begin{array}{l}\text { NO. OF } \\
\text { GHILDREN }\end{array}$} & \multirow{2}{*}{$\begin{array}{c}\text { NO. OF } \\
\text { CHILDREN } \\
\text { WITH NO } \\
\text { DME } \\
\text { TEETH }\end{array}$} & \multirow[b]{2}{*}{$\begin{array}{l}\text { PER CENT OF } \\
\text { CHILDREN WITH } \\
\text { NO DMF TEETH }\end{array}$} \\
\hline & $\left|\begin{array}{c}\text { NO. OF } \\
\text { CHILDREN }\end{array}\right|$ & \begin{tabular}{|c|} 
NO. OF \\
CHILDREN \\
WITH NO \\
DMF TEETH
\end{tabular} & $\begin{array}{l}\text { PER CENT OF } \\
\text { CHILDREN WITH } \\
\text { NO DMF TEETH }\end{array}$ & & & \\
\hline 6 & 47 & 32 & $68.09 \pm 6.8$ & 87 & 69 & $79.31 \pm 4.3$ \\
\hline 7 & 43 & 7 & $16.28 \pm 5.6$ & $10 \tilde{0}$ & 72 & $68.57 \pm$ \\
\hline 8 & 43 & 5 & $11.63 \pm 4.9$ & 72 & 36 & $50.0 \pm 5.8$ \\
\hline 9 & 56 & 8 & $14.29 \pm 4.6$ & 75 & 26 & $34.67 \pm 5.4$ \\
\hline 10 & 46 & 1 & $2.17 \pm 2.2$ & 86 & 26 & $30.23 \pm$ \\
\hline 11 & 57 & 3 & $5.26 \pm 2.9$ & 78 & 18 & $23.77 \pm$ \\
\hline 12 & 48 & 1 & $2.08 \pm 2.05$ & 75 & 19 & $25.33 \pm$ \\
\hline 13 & 60 & 1 & $1.67 \pm 1.6$ & 106 & 19 & $17.92 \pm$ \\
\hline 14 & 98 & 3 & $3.06 \pm 1.7$ & 91 & 14 & $15.38 \pm$ \\
\hline 15 & 27 & 0 & 0 & 79 & 13 & $16.45 \pm$ \\
\hline 16 & 13 & 0 & 0 & 32 & 3 & $9.38 \pm 5.1$ \\
\hline 17 & 3 & 0 & 0 & 8 & $\ddot{1}$ & $12.50 \pm 11.67$ \\
\hline $6-17$ & 541 & 61 & $11.25 \pm 1.4$ & 894 & 316 & $35.35 \pm 1.6$ \\
\hline
\end{tabular}


Table III. Decayed, Flllaed, and Deciduous Teeth Indicated for Extraction (DeF) Child IN EAYETTEVIILL AND PULASki IN 1948

\begin{tabular}{r|c|c|c|c|c|c}
\hline \hline \multirow{2}{*}{$\begin{array}{c}\text { AGE } \\
\text { (YR.) }\end{array}$} & \multicolumn{3}{|c|}{ FAYETTEVILLE } & \multicolumn{2}{c}{ PULASKI } \\
\cline { 2 - 8 } & $\begin{array}{c}\text { NO. OF } \\
\text { CHILDREN }\end{array}$ & $\begin{array}{c}\text { NO. DEF } \\
\text { TEETH }\end{array}$ & $\begin{array}{c}\text { DEF TEETH } \\
\text { PER CHILD }\end{array}$ & $\begin{array}{c}\text { NO. OF } \\
\text { CHILDREN }\end{array}$ & $\begin{array}{c}\text { NO. DEF } \\
\text { TEETH }\end{array}$ & $\begin{array}{c}\text { DEF TEETH } \\
\text { PER CHILD }\end{array}$ \\
\hline 6 & 47 & 374 & $7.96 \pm .74$ & 87 & 357 & $4.10 \pm .44$ \\
7 & 43 & 316 & $7.35 \pm .70$ & 105 & 393 & $3.74 \pm .38$ \\
8 & 43 & 270 & $6.28 \pm .53$ & 72 & 249 & $3.46 \pm .43$ \\
9 & 56 & 286 & $5.11 \pm .52$ & 75 & 267 & $3.56 \pm .40$ \\
10 & 46 & 162 & $3.52 \pm .51$ & 86 & 293 & $3.41 \pm .28$ \\
11 & 57 & 85 & $1.49 \pm .37$ & 78 & 94 & $1.21 \pm .28$ \\
12 & 48 & 25 & $.52 \pm .18$ & 75 & 26 & $.35 \pm .10$ \\
13 & 60 & 12 & $.20 \pm .07$ & 106 & 18 & $.17 \pm .06$ \\
\hline $6-8$ & 133 & 960 & $7.21 \pm .39$ & 264 & 999 & $3.77 \pm .24$ \\
$6-13$ & 400 & 1530 & $3.83 \pm .22$ & 684 & 1697 & $2.48 \pm .12$ \\
\hline
\end{tabular}

TABLE IV

Prevalence of Decayed, Missing, and Fllled (DMF) Teeith Per Child in Pulaski With REFERENCE TO SOURCE OF WATER AND PERIOD OF USE IN 1948

\begin{tabular}{|c|c|c|c|c|c|c|c|c|c|c|c|c|}
\hline \multirow[b]{2}{*}{$\begin{array}{c}\mathrm{AGE} \\
\text { (YR.) }\end{array}$} & \multicolumn{3}{|c|}{\begin{tabular}{|c|} 
CHILD. USING MUNICI- \\
PAL WATER SUPPLY \\
IN 1948 (MIXED \\
WATER HISTORIES FOR \\
MUNICIPAL WATER \\
SUPPLY) \\
\end{tabular}} & \multicolumn{3}{|c|}{$\begin{array}{l}\text { CHILD. USING WEIL } \\
\text { OR SPRING WATER IN } \\
1948 \text { (MIXED WATER } \\
\text { HISTORIES FOR WELIS } \\
\text { OR SPRINGS) }\end{array}$} & \multicolumn{3}{|c|}{$\left[\begin{array}{c}\text { CHIID. USING MUNICI- } \\
\text { PAL WATER CONT. } \\
\text { SINCE BIRTH (PURE } \\
\text { WATER HISTORIES FOR } \\
\text { MUNICIPAL WATER } \\
\text { SUPPLY) }\end{array}\right.$} & \multicolumn{3}{|c|}{$\begin{array}{c}\text { CHILD. USING WELL } \\
\text { OR SPRING WATER } \\
\text { CONT. SINCE BIRTH } \\
\text { (PURE WATER HIS- } \\
\text { TORIES FOR WELLS } \\
\text { OR SPRINGS) }\end{array}$} \\
\hline & $\begin{array}{l}\text { NO. OF } \\
\text { CHILD. }\end{array}$ & $\mid \begin{array}{c}\text { NO. OF } \\
\text { DME } \\
\text { TEETH }\end{array}$ & $\begin{array}{c}\text { NO. OF } \\
\text { DMF } \\
\text { TEETH } \\
\text { PER } \\
\text { CHILD }\end{array}$ & $\mid \begin{array}{ll}\text { NO. OF } \\
\text { CHILD. }\end{array}$ & $\mid \begin{array}{c}\text { NO. OF } \\
\text { DMF } \\
\text { TEETH }\end{array}$ & $\begin{array}{l}\text { NO. OF } \\
\text { DMF } \\
\text { TEETH } \\
\text { PER } \\
\text { CHILD }\end{array}$ & $\begin{array}{l}\text { NO. OF } \\
\text { CHILD. }\end{array}$ & $\mid \begin{array}{c}\text { NO. OF } \\
\text { DMF } \\
\text { TEETH }\end{array}$ & \begin{tabular}{|c|} 
NO. OF \\
DMF \\
TEETH \\
PER \\
CHYLD
\end{tabular} & $\begin{array}{l}\text { NO. OF } \\
\text { CHILD. }\end{array}$ & $\mid \begin{array}{c}\text { NO. OF } \\
\text { DMF } \\
\text { TEETH }\end{array}$ & \begin{tabular}{|l} 
NO. OF \\
DMF \\
TEETH \\
PER \\
OHILD
\end{tabular} \\
\hline 6 & 54 & 35 & $\begin{array}{r}.65 \\
\pm .21\end{array}$ & 33 & 9 & $\begin{array}{r}.27 \\
\pm .16\end{array}$ & 33 & 28 & $\begin{array}{r}.85 \\
\pm .32\end{array}$ & 26 & 5 & $\begin{array}{r}.19 \\
\pm .69\end{array}$ \\
\hline 7 & 74 & 51 & $\begin{array}{r}.69 \\
+.14\end{array}$ & 31 & 14 & $\begin{array}{r}.45 \\
+.15\end{array}$ & 54 & 41 & $\begin{array}{r}.76 \\
\pm .18\end{array}$ & 25 & 14 & $\begin{array}{r}.56 \\
\pm .18\end{array}$ \\
\hline 8 & 47 & 44 & $\begin{array}{r}.94 \\
+.18\end{array}$ & 25 & 31 & $\begin{array}{r}1.24 \\
\pm .32\end{array}$ & 33 & 31 & $\begin{array}{r}.94 \\
+.20\end{array}$ & 16 & 22 & $\begin{array}{l}1.38 \\
\pm 41\end{array}$ \\
\hline 9 & 46 & 79 & $\begin{array}{r}1.71 \\
+.22\end{array}$ & 29 & 61 & $\begin{array}{r}2.10 \\
+49\end{array}$ & 31 & 50 & $\begin{array}{r}1.61 \\
+2.35\end{array}$ & 23 & 42 & $\begin{array}{l}1.83 \\
\pm .48\end{array}$ \\
\hline 10 & 56 & 112 & $\begin{array}{r}2.00 \\
\pm .24\end{array}$ & 30 & 68 & $\begin{array}{l}2.27 \\
\pm .46\end{array}$ & 21 & 27 & $\begin{array}{l}1.29 \\
\pm .33\end{array}$ & 19 & 53 & $\begin{array}{l}2.79 \\
\pm .65\end{array}$ \\
\hline 11 & 48 & 76 & $\begin{array}{r}1.58 \\
\pm .23\end{array}$ & 30 & 101 & $\begin{array}{l}3.37 \\
\pm .48\end{array}$ & 28 & 43 & $\begin{array}{l}1.54 \\
\pm .30\end{array}$ & 15 & 49 & $\begin{array}{r}3.27 \\
\pm .72\end{array}$ \\
\hline 12 & 47 & 148 & $\begin{array}{r}3.15 \\
\pm .48\end{array}$ & 28 & 103 & $\begin{array}{l}3.68 \\
\pm .62\end{array}$ & 26 & 38 & $\begin{array}{l}1.46 \\
\pm .34\end{array}$ & 22 & 75 & $\begin{array}{l}3.41 \\
\pm .82\end{array}$ \\
\hline 13 & 54 & 214 & $\begin{array}{r}3.96 \\
\pm .49\end{array}$ & 52 & 212 & $\begin{array}{l}4.08 \\
\pm .46\end{array}$ & 24 & 76 & $\begin{array}{r}3.17 \\
+2.58\end{array}$ & 33 & 122 & $\begin{array}{l}3.70 \\
\pm .52\end{array}$ \\
\hline 14 & 49 & 202 & $\begin{array}{l}4.12 \\
\pm .51\end{array}$ & 42 & 205 & $\begin{array}{r}4.88 \\
\pm 1.22\end{array}$ & 11 & 19 & $\begin{array}{l}1.73 \\
\pm .63\end{array}$ & 27 & 106 & $\begin{array}{l}3.93 \\
\pm .74\end{array}$ \\
\hline 15 & 43 & 183 & $\begin{array}{l}4.26 \\
\pm .54\end{array}$ & 36 & 212 & $\begin{array}{l}5.89 \\
\pm .67\end{array}$ & 16 & 38 & $\begin{array}{r}2.38 \\
\pm .65\end{array}$ & 22 & 126 & $\begin{array}{l}5.73 \\
\pm .85\end{array}$ \\
\hline 16 & 15 & 126 & $\begin{array}{r}8.40 \\
\pm 1.21\end{array}$ & 17 & 94 & $\begin{array}{r}5.53 \\
\pm 1.02\end{array}$ & 5 & 39 & $\begin{array}{r}7.80 \\
\pm 1.92\end{array}$ & 10 & 51 & $\begin{array}{r}5.10 \\
\pm 1.45\end{array}$ \\
\hline 17 & 6 & 25 & $\begin{array}{r}4.17 \\
\pm 1.61\end{array}$ & 2 & 25 & $\begin{array}{l}12.5 \\
\pm 1.51\end{array}$ & 2 & 1 & $\begin{array}{r}.50 \\
+.50\end{array}$ & 0 & 0 & 0.00 \\
\hline $6-17$ & 539 & 1295 & $\begin{array}{l}2.40 \\
\pm .13\end{array}$ & 355 & 1135 & $\begin{array}{r}3.20 \\
\pm .19\end{array}$ & 284 & 431 & $\begin{array}{l}1.52 \\
\pm .12\end{array}$ & 238 & 665 & $\begin{array}{l}2.79 \\
\pm .22\end{array}$ \\
\hline
\end{tabular}


group of Pulaski, only the 6 to 8 year age group rate is significantly lower as it is for the 6 to 13 year age group as a whole. The def rate for the 6 to 8 age group appears to be of more significance than the DMF rate since so few permanent teeth have erupted in this period of the mixed dentition.

Table IV presents the data on the prevalence of decayed, missing, and filled permanent teeth in Pulaski in relation to the source of water and the period during which this source of water was used. There is a higher prevalence of DMF teeth for those children with mixed water histories who used well or spring water in 1948, than for those with mixed water histories who used municipal water supplies in 1948 for the age group 6 to 17 years of age. The results indicate that the difference is not consistent in all age groups, since only those for the 17 year age group and for the 6 to 17 age group are significant.

Table IV also shows that there is a slight but significant difference between the children who consumed municipal water continuously since birth and those who had consumed well or spring water continuously since birth. The DMF rate for the 6 to 17 year age group, consuming municipal water continuously since birth, is 1.52 teeth per child, whereas, the children consuming well or spring water continuously since birth had a DMF rate of 2.79 teeth per child. The difference between the children with mixed municipal water histories who had 2.40 DMF teeth per child and the group with pure municipal water histories who had 1.52 DMF teeth per child is significant, but the difference between the children with mixed water histories who consumed well or spring water (3.20 DMF teeth per child) and the children with pure water histories who consumed well or spring water continuously since birth (2.79 DMF teeth per child) is not statistically significant.

Table $\mathrm{V}$ relates the def prevalence rates compared to the source of water and the period of use. There is no significant difference in any of the def rates in Pulaski with reference to source of water and period of use.

Table VI presents data comparing the fluorosed permanent teeth in Pulaski with the source of water and the period of use. The difference in the number of fluorosed teeth per child of those using municipal water supply in 1948 (mixed municipal water histories) and of those using wells or springs in 1948 (mixed well or spring water histories) is significant for the 9 year age group, the 12 year age group, and the total age group 6 to 17 years of age, the other age groups not being significantly different. A comparison of the differences in fluorosed teeth per child of those using the municipal water supply continuously since birth (pure water histories of the municipal water supply) and those using wells or springs continuously since birth (pure water histories for wells or springs) indicates that the difference only for the 9 year age group and total group 6 to 17 is significant. The difference between the number of fluorosed teeth per child among those using the municipal water supply in 1948 (mixed histories for municipal water supply) and those using the municipal water supply continuously since birth (pure water histories for the municipal supply) is not significant for any individual age group or the total age group 6 to 17 years of age. The same observation holds true for the differences in 
TABLE V

Prevalence of Decayed, Filled and Deciduous Teeth Indicated for Extraction (Def) With Reference to Source of Water aNd Perion of USe tN PUlaski in 1948

\begin{tabular}{|c|c|c|c|c|c|c|c|c|c|c|c|c|}
\hline \multirow[b]{2}{*}{$\begin{array}{c}\text { AGE } \\
\text { (YR.) }\end{array}$} & \multicolumn{3}{|c|}{$\begin{array}{c}\text { CHILD, USING MUNIGI- } \\
\text { PAL WATER SUPPLY IN } \\
1948 \text { (MIXED WATER } \\
\text { HISTORIES FOR MU- } \\
\text { NICIPAL WATER } \\
\text { SUPPLY) }\end{array}$} & \multicolumn{3}{|c|}{$\begin{array}{l}\text { CHILD. USING WELL, } \\
\text { SPRING, OR CISTERN } \\
\text { WATER IN } 1948 \\
\text { (MIXED WATER HIS- } \\
\text { TORIES FOR WELIS } \\
\text { OR SPRINGS) }\end{array}$} & \multicolumn{3}{|c|}{\begin{tabular}{|c} 
CHILD. USING MUNICI- \\
PAL WATER CONT. \\
SINCE BIRTH (PLRE \\
WATER HISTORIES FOR \\
MUNICIPAL WATER \\
SUPPLY)
\end{tabular}} & \multicolumn{3}{|c|}{$\begin{array}{l}\text { CHILD, USING WELL, } \\
\text { SPRING, OR CISTERN } \\
\text { WATER CONT. SINCE } \\
\text { BIRTH (PURE WATER } \\
\text { IIISTORIES FOR WELLS } \\
\text { OR SPRINGS) }\end{array}$} \\
\hline & $\mid \begin{array}{l}\text { NO. OF } \\
\text { CHILD. }\end{array}$ & $\left|\begin{array}{c}\text { NO. OF } \\
\text { (DEF) } \\
\text { TEETH }\end{array}\right|$ & $\begin{array}{l}\text { NO. OF } \\
\text { (DEF) } \\
\text { TEETH } \\
\text { PER } \\
\text { CHILD }\end{array}$ & $\mid \begin{array}{ll}\text { No. OF } \\
\text { CHILD. }\end{array}$ & $\left|\begin{array}{c}\text { NO. OF } \\
\text { (DEF) } \\
\text { TEETH }\end{array}\right|$ & $\begin{array}{l}\text { NO. OF } \\
\text { (DEF) } \\
\text { TEETH } \\
\text { PER } \\
\text { CHILD }\end{array}$ & $\begin{array}{l}\text { NO. OF } \\
\text { CHILD. }\end{array}$ & $\mid \begin{array}{c}\text { NO. OF } \\
\text { (DEF) } \\
\text { TEETH }\end{array}$ & $\begin{array}{l}\text { NO. OF } \\
\text { (DEF) } \\
\text { TEETH } \\
\text { PER } \\
\text { CHILD }\end{array}$ & $\begin{array}{l}\text { No. OF } \\
\text { CHILD. }\end{array}$ & $\left|\begin{array}{c}\text { NO. OF } \\
\text { (DEF) } \\
\text { TEETH }\end{array}\right|$ & $\begin{array}{l}\text { NO. OF } \\
\text { (DEF) } \\
\text { TEETH } \\
\text { PER } \\
\text { CHILD }\end{array}$ \\
\hline 6 & 54 & 223 & & 33 & 134 & $\begin{array}{r}4.06 \\
+.68\end{array}$ & 33 & 119 & & 26 & 93 & $\begin{array}{r}3.58 \\
+1.81\end{array}$ \\
\hline 7 & 74 & 255 & & 31 & 138 & $\begin{array}{r}+4.45 \\
+.76\end{array}$ & 54 & $16: 1$ & & 25 & 117 & $\begin{array}{r}4.68 \\
+.90\end{array}$ \\
\hline 8 & 47 & 165 & & 25 & $8 \pm$ & $\begin{array}{l}3.36 \\
\pm 62\end{array}$ & 33 & 92 & & 16 & 44 & $\begin{array}{l}2.75 \\
\pm .65\end{array}$ \\
\hline 9 & 46 & 186 & $\begin{array}{l}4.0 \\
\pm .5\end{array}$ & 29 & 81 & $\begin{array}{l}2.79 \\
\pm .63\end{array}$ & 31 & 114 & & 23 & 64 & $\begin{array}{l}2.78 \\
\pm .94\end{array}$ \\
\hline 10 & 56 & 120 & $\begin{array}{l}2.14 \\
\pm .36\end{array}$ & 30 & 73 & $\begin{array}{l}2.43 \\
+.31\end{array}$ & 21 & 47 & $\begin{array}{l}2.24 \\
\pm .61\end{array}$ & 19 & 49 & $\begin{array}{l}2.58 \\
\pm .63\end{array}$ \\
\hline 11 & 48 & 49 & $\begin{array}{l}1.02 \\
\pm .22\end{array}$ & 30 & 45 & $\begin{array}{l}1.50 \\
\pm .35\end{array}$ & 28 & 35 & $\begin{array}{l}1.25 \\
\pm .46\end{array}$ & 15 & 21 & $\begin{array}{l}1.4 \\
\pm .61\end{array}$ \\
\hline 12 & 47 & 18 & $\begin{array}{r}.38 \\
\pm .19\end{array}$ & 28 & 8 & $\begin{array}{r}.29 \\
+.19\end{array}$ & 26 & 12 & $\begin{array}{r}.46 \\
\pm .32\end{array}$ & 22 & 7 & $\begin{array}{r}.32 \\
\pm .24\end{array}$ \\
\hline 13 & 54 & 11 & $\begin{array}{r}.20 \\
+.11 \\
\end{array}$ & 52 & 7 & $\begin{array}{r}.13 \\
\pm .07\end{array}$ & 24 & 3 & $\begin{array}{r}.13 \\
\pm .09\end{array}$ & 33 & 6 & $\begin{array}{r}.18 \\
+.10 \\
\end{array}$ \\
\hline $6-8$ & 175 & 643 & $\begin{array}{l}3.72 \\
\pm .30\end{array}$ & 89 & 356 & $\begin{array}{l}4.0 \\
\pm .41\end{array}$ & 120 & 375 & $\begin{array}{l}3.13 \\
\pm .33\end{array}$ & 67 & 254 & $\begin{array}{r}3.79 \\
\pm .78\end{array}$ \\
\hline $6-13$ & 426 & 1027 & $\begin{array}{l}2.41 \\
\pm .16\end{array}$ & 258 & 570 & $\begin{array}{l}2.21 \\
\pm .20\end{array}$ & 250 & 586 & $\begin{array}{l}2.34 \\
\pm .21\end{array}$ & 179 & 401 & $\begin{array}{r}2.24 \\
\pm .34 \\
\end{array}$ \\
\hline
\end{tabular}

fluorosed teeth per child in those children using well or spring water in 1948 (mixed water histories for wells or springs) and the children who used well or spring water continuously since birth (pure water histories for wells or springs). No fluorosis was observed in deciduous teeth and no fluorosed teeth were noted in the Fayetteville group. Of the fluorosed teeth noted in the $\mathrm{Pu}$ laski examinations, three cases of severe mottling were observed, the remainder being of mild type.

There is a vein of phosphate rock extending through the middle of Tennessee from the northern to the southern boundaries. The water supply of Fayetteville in Lincoln County is a spring in the highland rim. Scattered deposits of phosphate are found in Lincoln County but are not significant to the source of municipal water supply of Fayetteville since the fluoride determination of the water supply of Fayetteville has been and is $0.0 \mathrm{ppm}$. fluorine.

Richland Creek is the municipal water supply of Pulaski, Tenn., and it is fed by branches of several ereeks that flow through the richest layer of phosphate rock. The three richest layers of phosphate rock provide the highest amount of fluoride as $\mathrm{F}$. The three layers are the undifferentiated, the Bigby, and the Hermitage. The creek system of Giles County, which makes up the municipal water supply of Pulaski, is confined to the richest phosphate strata of the county. There is some distribution of phosphate rock in Lincoln County, 
TABLE VI

Fluorosed Permanent Teeth in Pulaski With Reference to Source of Water and PERIOD OF USE IN 1948

\begin{tabular}{|c|c|c|c|c|c|c|c|c|c|c|c|c|}
\hline \multirow[b]{2}{*}{$\begin{array}{c}\mathrm{AGE} \\
(\mathrm{YR} .)\end{array}$} & \multicolumn{3}{|c|}{$\begin{array}{l}\text { CHILD. USING MUNICI- } \\
\text { PAL WATER SUPPIY IN } \\
1948 \text { (MIXED WATER } \\
\text { HISTORIES FOR THE } \\
\text { MUNICIPAI WATER } \\
\text { SUPPLY) } \\
\end{array}$} & \multicolumn{3}{|c|}{$\begin{array}{l}\text { CHILD. USING WELL, } \\
\text { SPRING, OR CISTERN } \\
\text { WATER IN } 1948 \\
\text { (MIXED WATER HIS- } \\
\text { TORIES FOR WELLS } \\
\text { OR SPRING) } \\
\end{array}$} & \multicolumn{3}{|c|}{$\begin{array}{l}\text { CHILD. USING MUNIC- } \\
\text { IPAL WATER SUPPLY } \\
\text { CONT. SINCE BIRTH } \\
\text { (PURE WATER } \\
\text { HISTORIES) } \\
\end{array}$} & \multicolumn{3}{|c|}{$\begin{array}{l}\text { CHILD, USING WELLS, } \\
\text { SPRINGS, OR CISTERN } \\
\text { CONT. SINCE BIRTH } \\
\text { (PURE WATER } \\
\text { HISTORIES) } \\
\end{array}$} \\
\hline & $\begin{array}{l}\text { NO. OF } \\
\text { CHILD. }\end{array}$ & $\mid \begin{array}{c}\text { NO. OF } \\
\text { FLU. } \\
\text { TEETH }\end{array}$ & $\begin{array}{l}\text { NO. OF } \\
\text { FLU. } \\
\text { TEETH } \\
\text { PER } \\
\text { CHILD }\end{array}$ & $\begin{array}{l}\text { NO. OF } \\
\text { CHILD. }\end{array}$ & $\left|\begin{array}{c}\text { NO. OF } \\
\text { FLU. } \\
\text { TEETH }\end{array}\right|$ & $\begin{array}{l}\text { NO. OF } \\
\text { FLU. } \\
\text { TEETH } \\
\text { PER } \\
\text { CHILD }\end{array}$ & $\left|\begin{array}{ll}\text { NO. } & \text { OF } \\
\text { CHILD. }\end{array}\right|$ & $\left|\begin{array}{c}\text { NO. OF } \\
\text { FLU. } \\
\text { TEETH }\end{array}\right|$ & $\begin{array}{l}\text { NO. OF } \\
\text { FLU. } \\
\text { TEETH } \\
\text { PER } \\
\text { CHILD }\end{array}$ & $\mid \begin{array}{l}\text { NO. OF } \\
\text { CHILD. }\end{array}$ & $\left|\begin{array}{c}\text { NO. OF } \\
\text { FLU. } \\
\text { TEETH }\end{array}\right|$ & $\begin{array}{l}\text { NO. OF } \\
\text { FLU. } \\
\text { TEETH } \\
\text { PER } \\
\text { CHILD }\end{array}$ \\
\hline 6 & 5 & 12 & $\begin{array}{l}2.4 \\
\pm .63\end{array}$ & 1 & 3 & 3.0 & 3 & 8 & $\begin{array}{c}2.7 \\
\pm 1.17\end{array}$ & 1 & 3 & 3.0 \\
\hline 7 & 17 & 65 & $\begin{array}{l}3.8 \\
\pm .47\end{array}$ & 3 & 7 & $\begin{array}{l}2.3 \\
\pm .88\end{array}$ & 14 & 56 & $\begin{array}{l}4.0 \\
\pm .50\end{array}$ & 1 & 1 & 1.0 \\
\hline 8 & 21 & 128 & $\begin{array}{l}6.1 \\
\pm .88\end{array}$ & 6 & 33 & $\begin{array}{c}5.5 \\
\pm 1.52\end{array}$ & 19 & 117 & $\begin{array}{l}6.2 \\
\pm .74\end{array}$ & 4 & 21 & $\begin{array}{c}5.3 \\
+2.74 \\
\end{array}$ \\
\hline 9 & 19 & 129 & $\begin{array}{c}6.8 \\
\pm 1.14\end{array}$ & 5 & 8 & $\begin{array}{l}1.6 \\
\pm .40\end{array}$ & 18 & 126 & $\begin{aligned} & 7.0 \\
&+1.18\end{aligned}$ & 3 & 6 & $\begin{array}{l}2.0 \\
\pm .56\end{array}$ \\
\hline 10 & 19 & 170 & $\begin{array}{c}8.9 \\
+1.73\end{array}$ & 11 & 52 & $\begin{array}{r}4.7 \\
\pm 1.48\end{array}$ & 11 & 85 & $\begin{array}{r}7.7 \\
+2.39\end{array}$ & 9 & 41 & $\begin{aligned} & 4.6 \\
\pm & 1.75\end{aligned}$ \\
\hline 11 & 24 & 296 & $\begin{array}{l}12.3 \\
\pm 1.7\end{array}$ & 8 & 53 & $\begin{array}{r}6.6 \\
+2.57\end{array}$ & 19 & 214 & $\begin{array}{l}11.3 \\
\pm 1.70\end{array}$ & 4 & 24 & $\begin{array}{c}6.0 \\
\pm 3.45\end{array}$ \\
\hline 12 & 24 & 305 & $\begin{array}{l}12.7 \\
\pm 1.58\end{array}$ & 4 & 13 & $\begin{array}{l}3.3 \\
\pm .75\end{array}$ & 19 & 288 & $\begin{array}{l}15.2 \\
\pm 2.31\end{array}$ & 4 & 13 & $\begin{array}{l}3.3 \\
\pm .75\end{array}$ \\
\hline 13 & 19 & 189 & $\begin{array}{c}9.9 \\
+1.71\end{array}$ & 10 & 63 & $\begin{array}{c}6.3 \\
\pm 2.97\end{array}$ & 12 & 136 & $\begin{array}{l}11.3 \\
+2.86\end{array}$ & 6 & 36 & $\begin{array}{l}6.0 \\
\pm .80\end{array}$ \\
\hline 14 & 15 & 161 & $\begin{array}{l}10.7 \\
\pm 2.48\end{array}$ & 8 & 46 & $\begin{array}{c}5.8 \\
\pm 2.13\end{array}$ & 6 & 65 & $\begin{array}{l}10.8 \\
\pm 2.15\end{array}$ & 6 & 32 & $\begin{array}{r}5.3 \\
+2.57\end{array}$ \\
\hline 15 & 4 & 48 & $\begin{array}{l}12.0 \\
\pm 4.59\end{array}$ & 5 & 54 & $\begin{array}{l}10.8 \\
\pm 4.3\end{array}$ & 2 & 19 & $\begin{array}{c}9.5 \\
\pm 7.54\end{array}$ & 4 & 48 & $\begin{array}{l}12.0 \\
\pm 5.49\end{array}$ \\
\hline 16 & 3 & 31 & $\begin{array}{l}10.3 \\
\pm 6.18\end{array}$ & 1 & 1 & 1.0 & 1 & 8 & 8.0 & 0 & 0 & 0.0 \\
\hline 17 & 0 & 0 & 0.0 & 0 & 0 & 0.0 & 0 & 0 & 0.0 & 0 & 0 & 0.0 \\
\hline $6-17$ & 170 & 1534 & $\begin{array}{l}9.02 \\
\pm .57\end{array}$ & 62 & 333 & $\begin{array}{l}5.43 \\
\pm .81\end{array}$ & 124 & 1122 & $\begin{array}{c}9.04 \\
\pm 6.7 \\
\end{array}$ & 42 & 225 & $\begin{array}{r}5.36 \\
+1.02 \\
\end{array}$ \\
\hline
\end{tabular}

but there is very little of the rich Bigby formation found in that county and none is found close to Fayetteville, Tenn., which has a spring as the source of its municipal water supply. The community of Wales, just north of Pulaski on Richland Creek, is the location of a phosphate processing plant which was thought to be the source of the fluoridation of Richland Creek. The three patients with severe cases of mottled enamel detected in the Pulaski examinations came from Wales, which has no municipal water supply.

Tables VII and VIII present the fluorine, in ppm., that is found in the municipal water supplies of Fayetteville and Pulaski distribution systems. The Fayetteville distribution system constantly had $0.0 \mathrm{ppm}$. fluorine, while the samples of the Pulaski water provided levels that ranged between 0.2 and 1.0 ppm. fluorine.

Fluorine determinations were made on raw untreated water of Richland Creek before it entered the water treatment plant at Pulaski. On Nov. 18, 1948 , the water at the bridge and at the plant had $0.5 \mathrm{ppm}$. of fluorine, while that in the municipal system had $0.20 \mathrm{ppm}$. 
TABISE VIJ.

Fluokine Determinations of Municipal Water Supplites

\begin{tabular}{|c|c|c|c|}
\hline \multicolumn{2}{|c|}{ FAYETTEVILLF SYSTEM } & \multicolumn{2}{|c|}{ PULASKI SYSTEM } \\
\hline DATE & FLUORINE PPM. & DATE & FLUORINE PPM. \\
\hline $10 / 18 / 48$ & 0.0 & $8 / 10 / 48$ & 0.20 \\
\hline $10 / 20 / 48$ & 0.0 & $8 / 16 / 48$ & $0.80^{*}$ \\
\hline $10 / 26 / 48$ & 0.0 & $9 / 2 / 48$ & $0.70^{*}$ \\
\hline $10 / 26 / 48$ & 0.0 & $9 / 14 / 48$ & $0.80^{*}$ \\
\hline $11 / 9 / 48$ & 0.0 & $9 / 30 / 48$ & $1.00^{*}$ \\
\hline $11 / 9 / 48$ & 0.0 & $10 / 6 / 48$ & $0.50^{*}$ \\
\hline $11 / 17 / 48$ & 0.0 & $10 / 19 / 48$ & 0.50 \\
\hline $11 / 17 / 48$ & 0.0 & $11 / 18 / 48$ & 0.40 \\
\hline $11 / 17 / 48$ & 0.0 & $11 / 18 / 48$ & $0.20^{*}$ \\
\hline
\end{tabular}

* Duplicate samples analyzer.

TABLE VIII

Fluorine Determinations of Municipai, Water Supplies 32

\begin{tabular}{c|c}
\hline \multicolumn{2}{c}{ PULASKI SAMPLES } \\
\hline DATE & FLUORINE PPM. \\
\hline $4 / 21 / 50$ & 1.3 \\
$4 / 22 / 50$ & 0.3 \\
$4 / 23 / 50$ & 0.3 \\
$4 / 24 / 50$ & 0.3 \\
$4 / 25 / 50$ & 0.4 \\
$4 / 26 / 50$ & 1.2 \\
$4 / 27 / 50$ & 1.1 \\
\hline
\end{tabular}

DISCUSSION

The findings indicate that the children of Pulaski have fewer DMF teeth than those of Fayetteville, because they consume a water supply that contains intermittently high amounts of fluorine. Correspondingly, a greater percentage of the children in Pulaski have no DMF teeth. The def rates per child do not agree with those reported by Klein ${ }^{15}$ and Bull $^{5}$ but do indicate that there is a noticeable effect on the deciduous teeth of the children in Pulaski who consume the water which passes over the phosphate-bearing rock in the Giles County area.

When the Pulaski DMF rates are considered in relation to the source of water and the period of use, it is found that the ehildren using the municipal water supply continuously since birth have a lower DMF rate per child than those using the water from the municipal supply in 1948. There is a lower DMF rate per child for those using the municipal water supply continuously since birth and those using wells or springs continuously since birth, indicating the possibility that the ground water of Giles County in the phosphate rock area is not as high in fluorine content as the surface water. It would have been of interest to compare the fluoride content of well or spring waters and the river or creek water throughout Giles County.

Since the def rates per child of the Pulaski children in relation to source of water and period of use are not statistically significant, the rates will not be discussed nor any conclusions attempted, although they do seem to indicate that the effect of the fluoride water on the deciduous teeth is not as great as that observed on the permanent teeth. 
The mottled enamel in all but three children observed in these examinations was of the mild or very mild type. More fluorosed teeth and fewer DMF teeth per child were detected in the children using the municipal water supply with a mixed or continuous exposure to fluoride waters. The difference seems to indicate again that the creek and river waters of the phosphate area in Giles County have a higher fluorine content than do the well or spring waters of this area.

The Giles County area is rich in a phosphate that contains a high fluorine (F) content. The municipal water supply of Pulaski was not accidentally fluoridated, since the results indicate a relative benefit to those children who had used the wells and springs of Giles County. Since the watershed of Richland Creek flows through the richest of phosphate fields it is possible that this creek, as the source of the municipal water for Pulaski, has a greater fluorine content than does the well or spring water of the area because the undifferentiated, the Bigby, and Hermitage layers are the layers richest in phosphate and have the highest fluorine (F) content.

The water samples taken in the Pulaski distribution system are intermittent in $\mathrm{F}$ content while the samples taken in Fayetteville are constantly zero. Arnold $^{3}$ has suggested that $0.5 \mathrm{ppm}$. is necessary before appreciably low experience of dental caries ean be observed. The data submitted in this paper would seem to indicate that a lessened dental caries can be experienced with an intermittent fluoridation varying from day to day in the fluorine concentration.

\section{SUMMARY}

Mouth mirror and explorer examinations were made of the teeth of 894 white children 6 to 17 years of age in the Pulaski elementary and high schools. From Fayetteville schools 542 children served as controls, the municipal water supply of that town containing no trace of fluoride. The dental examinations of the two examiners were similar and standardized, and the impression of the examiners was that the children examined in Pulaski and Fayetteville had similar dietary and economic status.

The data indicate that the children using the water of the Pulaski area have fewer DMF teeth than do the children using the water from the Fayetteville area. The def rate per child of the Pulaski group was found to be 2.48 teeth per child for the 6 to 13 year age group and 3.77 teeth per child in the 6 to 8 year age group. For the Fayetteville group the def rate per child for the 6 to 13 year age group was 3.83 , and for the 6 to 8 year age group was 7.21 . There was a lower DMF rate per child in those children using the municipal water supply in 1948 with mixed exposure (2.40 for the age group 6 to 17 years of age) and for those using the municipal water supply with a constant exposure (1.52 for the 6 to 17 year age group) than for those using wells or springs with continuous exposure (2.79 for the 6 to 17 year age group).

The municipal water supply of Pulaski, which is Richland Creek, is fed by a system of ereeks that flow over and through regions rich in phosphate rock that have a high fluorine $(F)$ content. The intermittent fluoridation of the waters of 
Richland Creek is caused by the waters flowing through the areas rich in phosphate and the concentration of the fluoride in the water and appears to be related to the amount of water saturation in the ground.

The results of this study indicate that there is a definite relation between the phosphate rock of the area and the fluoride content found in the ground and surface water of the area. The richer the phosphate rock in this area the higher the fluorine content that can be expected in the water.

\section{CONCLUSIONS}

1. The lower DMF and def rates in Pulaski are due to the presence of fluoride in water of that area.

2. The lower DMF rate in the children using the municipal water in 1948 and continuously since birth is due to the presence of a greater fluoride concentration in the creeks of the Pulaski area.

3. The higher prevalence of mottled enamel observed in the Pulaski children who had consumed the municipal water in 1948 or continuously since birth is due to the greater fluoride concentration in the creeks of the Pulaski area.

4. The intermittent fluoridation appears to be due to creeks passing over phosphate rock rich in fluorides at varying rates of speed.

5. There seems to be a definite relation between the phosphate rock of this area and the fluoride content of the water of the same area.

6. A beneficial effect of fluoridation on teeth can be observed when the water supply is intermittently fluoridated in a range of 0.2 to $1.0 \mathrm{ppm}$.

\section{REFERENCES}

1. Alexander, F. M.: Geological Division, Tennessee Department of Conservation. Personal communieation, April 10, 1950.

2. Arnold, F. A., Jr.: Fluorides in Preventive Dentistry, J. A. D. A. 30: 499-508, 1943.

3. Arnold, F. A., Jr.: Fluorine in Drinking Water; Its Effeet on Dental Caries, J. A. D. A. 36: $28-36,1948$.

4. Arnold, F. A., Jr.: Evaluation of the Effectiveness as Caries Control Measures of Ingested Fluorides in Water, Food, Bone Flour, and Proprietary Preparations, J. D. Res. 27: 267-273, 1948.

5. Bull, $\vec{F}^{\text {. A.: }}$ Water Fluorination; Proves Its Value, D. Digest 55: 257-261, 1949.

6. Dean, H. T.: Chronic Endemic Dental Fluorosis; Mottled Enamel, J. A. M. A. 107: 1269-1272, 1936.

7. Dean, H. T.: Classification of Mottled Enamel Diagnosis, J. A. D. A. 21: 1421-1426, 1934.

8. Dean, H. T.: Distribution of Mottled Enamel in the United States, J. A. D. A. 20: 319-333, 1933 .

9. Dean, H. T.: Endemic Fluorosis and Its Relation to Dental Caries, Pub. Health Reports 53: $1443-1452,1938$.

10. Dean, H. T., Jay, P., Arnold, F. A., Tr., and Elvove, E.: Domestic Water and Dental Caries; II. A Study of 2,832 White Children, Aged 12-14 Years, of 8 Suburban Chicago Communities, Including Lactobacillus Acidophilus Studies of 1,761 Children, Pub. Health Reports 56: 761-792, 1941.

11. Dean, H. T., and Arnold, F. A., Jr.: Domestic Water and Dental Caries; V. Additional Studies of the Relation of Fluoride Domestic Waters to Dental Caries Experience in 4,425 White Children, Aged 12 to 14 Years, of 13 Cities in 4 States, Pub. Health Reports 57: 1155-1179, 1942.

12. Farrell, R. P.: Personal communication, Jan. 27, 1950.

13. Hardgrove, T. A., and Bull, F. A.: Fluorine and Deciduous Teeth, J. A. D. A. 34: 32-35, 1947.

14. Klein, H.: Dental Caries (DMF) Experience in Reloeated Children Exposed to Water Containing Fluorine, J.A. D. A. 33: 1136-1141, 1946. 
15. Klein, H.: Dental Effects of Accidentally Fluorinated Water; I. Dental Caries Experience in Deciduous and Permanent Teeth of School Age Children, J.A. D. $A$. 36: 443-453, 1948.

16. Klein, H.: The Family and Dental Disease; V. Caries Experience Among Parents and Offspring Exposed to Drinking Water Containing Fluoride, Pub. Health Reports 62: $1247-1253,1947$.

17. Klein, H.: Dental Caries Experience in Relocated Children Exposed to Water Containing Fluorine; I. Incidence of Caries After 2 Years of Exposure Among Previously Caries-Free Permanent Teeth, Pub. Health Reports 60: 1462-1467, 1945.

18. Pelton, W. J.: Dental Caries Data Obtained by Simplified Method and Correlated With Fluorine Data in Four Wyoming Cities, J. A. D. A. 38: 723-731, 1949.

19. Russell, A. L.: Dental Effects of Exposure to Fluoride-Bearing Dakota Sandstone Waters at Various Ages and for Various Lengths of Time; I. Status of the Permanent Teeth of 339 Children Aged 11 to 15 Years Who Used Such Water for Eighteen Months Prior to Eruption of the First Permanent Molars, J. D. Res. 28: $298-309,1949$.

20. Russell, A. L.: Dental Effeets of Exposure to Fluoride-Bearing Dakota Sandstone Waters at Various Ages and for Various Lengths of Time; II. Patterns of Dental Caries Inhibition as Related to Exposure Span, to Elapsed Time Since Exposure, and to Periods of Calcification and Eruption, J. D. Res. 28: 600-612, 1949.

21. Smith, M. C., Lantz, E., and Smith, H. V.: The Cause of Mottled Enamel, J. D. Res. 12: $149-159,1932$.

22. Smith, R. W., and Whitlatch, G. I.: The Phosphate Resources of Tennessee, Nashville, State of 'Tenn., Dept. of Conservation, Div. of Geology, Bull. 48, pp. 13-14, 1940.

23. Ibid.: p. 21.

24. Ibid.: pp. $33-43$.

25. Ibid.: p. 239.

26. Ibid.: pp. $210-219$.

27. Editorial: The Role of Fluorine in Dental Caries; IIT. Fluorination of Drinking Water, J. A. D. A. 34:690-691, 1947.

28. Velu, H.: Le'darmous; fluorose spontanee des zones phosphates Algirie Institut, Pasteur Arch. 10: 41-118, 1932.

29. Wilson, C. W., Jr.: Progress Geologic Map of Middle Tennessee. Nashville State of Tennessee, Dept. of Conservation, Div. for Geology, 1940. (Map.)

30. Churchill, H. V.: The Occurrence of Fluorides in Some Waters of the United States, J. D. Res. 12: 141-148, 1932.

31. Dean, H. T.: Further Studies on the Minimal Threshold of the Dental Signs of Chronic Endemic Fluorosis (Mottled Enamel), Pub. Health Reports 52: 1249-1264, 1937.

32. Finney, J. W., Jr.: Personal communication, May 10, 1950.

33. McKay, F. S.: Mottled Teeth; and Endemic Developmental Imperfection of the Enamel of the Teeth Heretofore Unknown in the Literature of Dentisty, D. Cosmos 58: $477-484,1916$.

34. Smith, M. C., and Leverton, R. M.: Comparative Toxicity of Fluorine Compounds, Ind. Engin. Chem. 26: 791-797, 1934. 